\title{
Pemanfaatan Internet Sebagai Media Masyarakat Pada Layanan Perpustakaan di Masa Pandemi COVID-19
}

\author{
Fahrun Nisak Alhusna \\ Pascasarjana UIN Sunan Kalijaga Yogyakarta \\ E-mail: fahrunnisak1301@gmail.com
}

\begin{abstract}
The progress of information and communication technology (ICT) is currently growing rapidly. so that a new media called the Internet was born. The internet has made it easier for people to communicate without knowing the barriers of space and time. Its use is like providing space for people to interact more easily and quickly. This interaction exists both in individuals and groups. This article uses a descriptive qualitative research method with a literature study approach. Based on the results of the study, the use of the internet network can make it easier for libraries to provide services to users or virtual communities which were originally developed face-to-face and then turned into online services during the COVID-19 pandemic. In addition, it provides convenience for users who need information by providing electronic sources of information for users who need access via the internet. As a support unit in the field of education, libraries during the COVID-19 pandemic must continue to provide good service to their users so that the library remains busy and up to date.
\end{abstract}

Keywords: Internet, Library Service, Covid-19

\begin{abstract}
Abstrak
Kemajuan teknologi informasi dan komunikasi (TIK) saat ini berkembang pesat. sehingga lahirlah media baru yang disebut dengan Internet. Internet telah memudahkan masyarakat untuk berkomunikasi tanpa mengenal sekat ruang dan waktu. Penggunaannya seperti memberi ruang bagi orang untuk berinteraksi dengan lebih mudah dan cepat. Interaksi ini terjalin baik pada individu maupun kelompok. Artikel ini menggunakan metode penelitian kualitatif deskriptif dengan pendekanan studi pustaka. Berdasarkan hasil penelitian, pemanfaatan jaringan internet dapat mempermudah perpustakaan dalam memberikan layanan kepada pemustaka atau masyarakat virtual yang semula dikembangkan secara tatap muka kemudian diubah menjadi layanan online di masa pandemi covid-19. Selain itu, memberikan kemudahan bagi pemustaka yang membutuhkan informasi dengan menyediakan sumber informasi elektronik bagi pemustaka yang membutuhkan dengan mengakses
\end{abstract}

Tik Ilmeu : Jurnal Ilmu Perpustakaan dan Informasi IAIN Curup | p-issn: 2580-3654; e-issn:2580-3662

DOI: $10.29240 /$ tik.v5i2.3095 
melalui internet. Sebagai unit pendukung di bidang pendidikan, perpustakaan di masa pandemi covid-19 harus tetap memberikan pelayanan yang baik bagi pemustakanya agar perpustakaan tetap ramai dan tetap up to date.

Kata Kunci: Internet; Layanan Perpustakaan; Covid-19.

\section{A. PENDAHULUAN}

Dalam beberapa tahun terakhir, teknologi informasi dan komunikasi (TIK) berkembang pesat. Hal ini menandakan bahwa internet telah menjadi alat komunikasi utama yang banyak diminati oleh berbagai kalangan. Mulai dari anak SD, para generasi muda, hingga orang tua memanfaatkan internet. Setelah internet mulai dapat diakses melalui Handphone, penggunaan internet sebagai sarana komunikasi menjadi semakin cepat dan mudah, bahkan muncul istilah telepon pintar (smartphone). Salah satu keunggulan smartphone ialah dapat mengunduh berbagai macam aplikasi social networking yang dapat memudahkan penggunanya dalam berkomunikasi maupun penyebaran informasi satu dengan yang lainnya. Tentunya smartphone tersebut terhubung ke internet. Aplikasi tersebut ialah seperti WhatsApp, telegram, wechat, facebook, twitter, instagram dan lain sebagainya. Selain itu, dengan salah satu aplikasi tersebut masyarakat dapat mengakses berita yang terjadi di dunia. Melalui internet juga, masyarakat dapat mengetahui peristiwa-peristiwa apa saja yang terjadi di dunia baik berita sosial, lingkungan, politik, gaya hidup, ekonomi dan lain sebagainya.

Tanpa disadari, produk teknologi sudah menjadi kebutuhan dalam kehidupan sehari-hari oleh masyarakat Indonesia. Penggunaan smartphone dan komputer yang terhubung ke internet sudah bukan menjadi hal yang tabu dan baru, terutama di kota-kota besar. Hal ini di buktikan oleh sebuah survei yang dilakukan oleh Asosiasi Penyelenggara Jasa Internet Indonesia (APJII) yang menyatakan bahwa pertumbuhan pengguna internet di Indonesia dari tahun ke tahun terus mengalami peningkatan. Berikut merupakan gambar diagram hasil survei yang dilakukan oleh Asosiasi Penyelenggara Jasa Internet Indonesia (APJII) di Indonesia (Laugu, 2021).

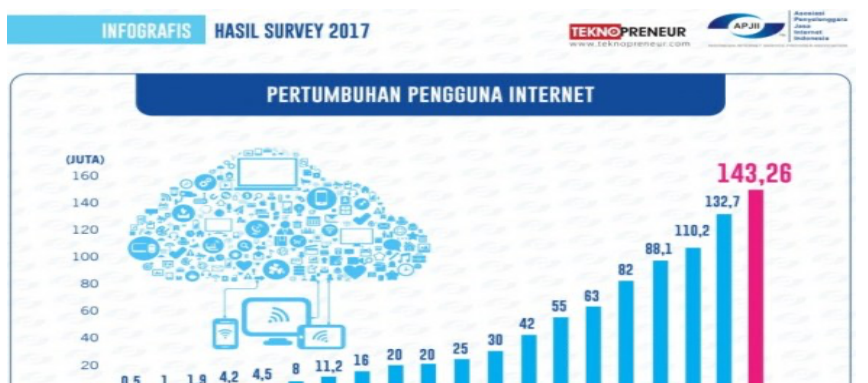


Gambar 1. Diagram hasil survei yang dilakukan oleh Asosiasi Penyelenggara Jasa Internet Indonesia (APJII) di Indonesia

Dari diagram di atas dapat dilihat pada tahun 2017 merupakan tahun dengan jumlah pengguna internet terbesar, yaitu dari jumlah populasi penduduk Indonesia sekitar 262 juta jiwa, sebanyak 143,26 juta jiwa yang menggunakan internet. Jumlah ini meningkat 10,56 juta jiwa, jika dibandingkan dengan pengguna internet pada tahun 2016. Sementara itu, berikut adalah grafik hasil survei tingkat penetrasi pengguna Internet Indonesia yang dilakukan oleh APJII pada tahun 2016. (Laugu, 2021).

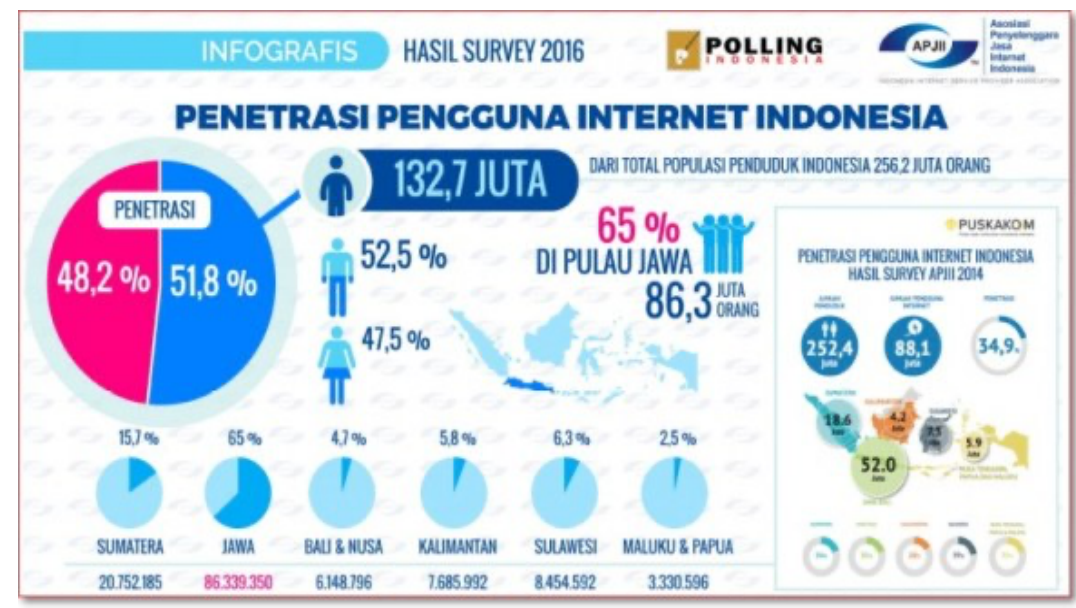

Gambar 2. Grafik hasil survei tingkat penetrasi pengguna Internet Indonesia yang dilakukan oleh APJII pada tahun 2016

Dari hasil survei di atas, terlihat bahwa pulau jawa memiliki jumlah pengguna Internet terbesar, yaitu 86,3 juta tepatnya, atau sekitar 58,08\%. Pada saat yang sama, Maluku dan Papua memiliki jumlah pengguna Internet paling sedikit, tepatnya $2,5 \%$. Hasil dari dua survei di atas menunjukkan bahwa Internet telah banyak digunakan oleh masyarakat Indonesia. Tidak heran Internet telah memungkinkan dunia untuk melihat dunia baru, yaitu 
interaksi secara global dan instan untuk berkomunikasi antar belahan dunia lainnya tanpa batas, ruang dan waktu.

Disadari bahwa perkembangan teknologi informasi dan komunikasi yang disebut internet, telah mengubah pola interaksi masyarakat, yaitu; interaksi sosial, komersial, ekonomi dan budaya. Internet telah memberikan kontribusi yang signifikan bagi masyarakat, industri, perusahaan dan pemerintah. Salah satu keberadaan internet mendukung efektifitas dan efisiensi operasional perpustakaan, terutama peranannya sebagai sarana komunikasi dalam memberikan pelayanan perpustakaan, dan memberikan berbagai informasi yang dibutuhkan oleh pemustaka.

Perkembangan internet ini juga berpengaruh pada perkembangan jenis ataupun tipe komunitas di masyarakat. Biasanya komunitas ini muncul dari keseragaman ide dan minat yang memiliki ketertarikan yang sama. Sehingga mereka membuat komunitas yang disebut dengan grup virtual untuk mempermudah mobilitas bersama. Komunitas vitual ini tidak terbatas oleh ruang dan waktu. Oleh karena itu tak heran jika saat ini masyarakat lebih banyak menggunakan internet sebagai media komunikasi.

Sejak akhir tahun 2019 dunia dilanda dengan sebuah virus yang disebut coronavirus disease 2019 atau covid-19. Masa pandemi Covid-19, seakan kehidupan masyarakat berada dalam budaya yang baru termasuk Indonesia. Berbeda dengan budaya di masa normal manakala semua aktivitas berjalan dengan normal dan interaksi sosialpun tidak terganggu oleh situasi yang memerlukan perhatian khusus. Namun berbeda pada masa pandemi Covid-19 ini, dimana interaksi sosial dibatasi, tidak diperbolehkan berada dalam keramaian, menggunakan masker, selalu cuci tangan dan sebagainya, sehingga hal ini berdampak pada pelayanan perpustakaan.

Pada masa pandemi Covid-19 ini pelayanan perpustakaan hampir tidak dilakukan secara langsung (offline), pemustaka tidak bisa datang ke perpustakaan, tidak bisa diskusi bersama rekannya, tidak bisa mengerjakan tugas-tugas akademisnya, dan aktivitas lainnya di perpustakaan. Akibatnya perpustakaan menjadi ruang kosong yang diisi oleh pustakawan yang mendapat giliran piket. Perpustakaaan tidak lagi ramai dikunjungi oleh pemustaka dan menjadi tempat sunyi dari budaya akademis yang biasanya terlihat ramai.

Sesuai instruksi pemerintah, untuk mencegah penyebaran Covid-19, berbagai pelayanan perpustakaan ditutup sementara. Namun, sebagai lembaga yang bertanggung jawab dalam mengelola informasi dan memberikan layanan pengetahuan kepada masyarakat, perpustakaan dituntut untuk dapat mempertahankan eksistensinya dengan tetap memberikan pelayanan yang baik kepada masyarakat pemustaka. Perpustakaan seolah- 
olah ditantang oleh lingkungan dan tidak dapat mengatasi situasi abnormal ini. Oleh karena itu, perpustakaan di masa pandemi Covid-19 harus mampu memberikan berbagai inovasi pelayanan perpustakaan untuk menjaga eksistensi perpustakaan, dan pengguna tidak akan kehilangan akses informasi seperti keadaan normal. Namun dalam hal pandemi covid-19 untuk mengakses informasi dapat dengan strategi dan metode yang berbeda.

Saat ini beberapa studi telah melakukan penelitian terkait internet dan masyarakat virtual seperti yang dilakukan oleh Mukhtar Effendi (2010) dengan judul "Peranan Internet sebagai Media Komunikasi", kemudian penelitian yang dilakukan oleh Putri Maulina (2018) dengan judul "Warung Kopi, Masyarakat Virtual, Dan Hiperealitas (Ketika Warung Kopi Mengaburkan Batasan Realita)", terakhir penelitian yang dilakukan oleh Shinta Nofita Sari (2018) dengan judul "Perilaku Demokratik Masyarakat Virtual (Studi Kasus: Pemustaka Perpustakaan Uin Sunan Kalijaga Yogyakarta)". Sedangkan penelitian ini akan mengkaji internet sebagai media masyarakat virtual pada pelayanan perpustakaan di masa pandemi covid-19. Dengan demikian, penelitian ini bertujuan untuk mengetahui bagaimana perpustakaan mempertahankan eksistensinya dalam memberikan pelayanan daring kepada pemustaka pada masa pandemi covid-19.

Dalam penelitian ilmiah, metode penelitian sangatlah penting, agar penelitian dapat lebih tepat sasaran. Menurut Lexi (2008), "Metode penelitian adalah usaha untuk menemukan, mengembangkan, dan menguji suatu kebenaran pengetahuan dengan cara-cara ilmiah. Oleh karena itu, metode yang digunakan harus tepat." Artikel ini menggunakan metode penelitian kualitatif deskriptif dengan pendekaan studi pustaka. Studi pustaka merupakan metode pengumpulan data dengan melakukan telaah terhadap karya tulis seperti buku, catatan dan laporan-laporan yang memiliki hubungan untuk menjawab masalah yang ditemukan (Nazir, 2007). Dalam artikel ini sumber data yang digunakan yaitu berasal dari jurnal dan buku.

\section{B. HASIL DAN PEMBAHASAN}

Internet terdapat di mana-mana dalam kehidupan sehari-hari manusia. Melalui internet, kita dapat mencari informasi, merencanakan perjalanan, membaca koran, artikel, berkomunikasi dengan orang lain dengan memanfaatkan e-mail, pesan instan, chat room, telepon internet, papan diskusi, dan konferensi video. Bahkan melalui internet kita dapat mendengarkan musik dan radio, nonton video, pesan atau membeli atau menjual sesuatu dengan melelang barang yang berbeda, menulis blog kita sendiri, dan berkontribusi pada blog orang lain. Dengan internet juga kita 
dapat bertemu dengan orang lain walaupun dalam keadaan keterbatasan jarak yang jauh.

Teknologi informasi dan komunikasi (TIK) merupakan istilah yang digunakan untuk teknologi kognisi, komunikasi, dan kerjasama yang terkomputerisasi (yaitu, bekerja dengan logika digital) dan jaringan. Istilah Internet sering digunakan untuk jenis TIK tertentu, jaringan global, jaringan komputer yang didasarkan pada protokol TCP/IP yang telah dikembangkan dari ARPANET (Christian, 2008).

Menurut Onno W. Purbo yang merupakan seorang pakar internet asal Indonesia dalam Layla Umayya (2021) , menjelaskan "internet pada dasarnya merupakan media yang digunakan untuk mengefesiensikan proses komunikasi". Sedangkan menurut tim penelitian dan pengembangan wahana computer 2005 dalam (Layla Umayya, 2021) "Internet adalah metode untuk menghubungkan berbagai komputer ke dalam satu jaringan global, melalui protokol yang disebut Transmission Control Protocol / Internet Protocol $(T C P / I P)$ ".

Dengan demikian dapat disimpulkan bahwa internet dapat mempermudah manusia dalam berinteraksi. Internet menggambarkan istilah untuk sekumpulan jaringan komputer ataupun suatu jaringan komunikasi antar komputer serta smartphone yang mencakup seluruh dunia dan berbasis pada suatu protokol yang menyediakan akses untuk layanan telekomunikasi serta sumber daya informasi untuk jutaan pemakainya yang tersebar di seluruh dunia.

Filosofi teknologi oleh Don Ihde adalah studi tentang interaksi material antara manusia dan teknologi dalam kehidupan sehari-hari dan antara manusia dan dunia yang berhubungan dengan teknologi (Fancis Lim, 2008). Dengan kata lain, manusia yang hidup dalam perkembangan ini tidak luput dari perkembangan teknologi.

Pada akhir abad ke-20, muncul fenomena baru dalam proses komunikasi manusia, yaitu penggunaan internet secara teknis dan fisik. Sehingga hal ini telah menjadi bagian tak terpisahkan dari masyarakat, pendidikan, industri dan pemerintah. Secara akademis, penggunaan Internet untuk komunikasi adalah konsep dan bidang penelitian yang relatif baru, dan belum banyak tersentuh.

Beberapa ahli di media Internet telah berkontribusi pada terminologi komunikasi penggunaan media Internet atau computer mediated communication. Pixy Ferris dalam Mukhtar Effendi (2010) secara umum 
mendefinisikan komunikasi menggunakan Internet sebagai "interaksi antarpribadi melalui koneksi komputer, termasuk komunikasi asynchronous dan synchronous melalui fasilitas di Internet." Selain itu, John December mendefinisikannya sebagai "telekomunikasi yang menggunakan banyak komputer." Pada saat yang sama, terminologi yang berlaku, komunikasi menggunakan Internet adalah "penggunaan komputer dan fasilitas serta kemampuannya sebagai sarana penyampaian informasi, baik itu publik atau individu" (Brittney, 1998).

Secara khusus proses komunikasi menggunakan media internet dapat digambarkan sebagai berikut:

a. Menciptakan pengertian dengan menulis "surat" melalui e-mail, menuliskan kata-kata pada waktu yang sama dalam komunitas chatting, serta menciptakan websites melalui penciptaan file multimedia;

b. Menyebarkan pengertian melalui komunikasi point to point (E-mail), dan komunikasi point to multi point (IRc, Website);

c. Merasakan arti dalam teks dan multimedia padawebsites, email dan IRC; dan

d. Berpartisipasi dalam forum untuk awal penjelajahan karakteristik komunitas seperti tujuan bersama, norma-norma dan tradisi. (Mukhtar Effendi, 2010)

Dengan demikian, hal ini dapat disimpulkan bahwa internet telah membawa banyak perubahan dalam kehidupan masyarakat. Hal ini dikarenakan banyaknya kemudahan yang diberikan oleh internet, sehingga kini internet dapat digolongkan sebagai salah satu media komunikasi. Kemunculan internet telah memberikan dampak positif dan negatif bagi masyarakat dalam bidang pendidikan, industri, pemerintahan, dan berbagai bidang lainnya.

Internet telah banyak mengambil peran di kehidupan manusia baik dari segi positif maupun negatif. Setelah terhubung dengan internet setiap orang dapat mengakses berbagai informasi, maupun berkomunikasi dengan orang lain melalui dunia maya dengan memanfaatkan e-mail, atau pesan instan lainnya. Internet juga menghadirkan komunitas di dunia maya yang dikenal sebagai virtual community. Dalam hal ini individu maupun kelompok menggunakan media internet untuk berkomunikasi lewat dunia maya.

Komunitas virtual adalah kumpulan pengguna Internet yang membentuk jaringan hubungan pribadi. Konsep virtualitas bermula dari adanya "bandwidth", yang merupakan simbol utama untuk terhubung dengan dunia virtual. Tanpa disadari, komunitas manusia saat ini hidup dalam dua 
dunia kehidupan, yaitu kehidupan nyata dan komunitas online. Bahkan hal ini telah menjadikan manusia, baik individu maupun kelompok, semakin tertarik untuk berkomunikasi di dunia maya (Manalu, 2017).

Rheingold (1995) dalam Rulli (2015) berpendapat bahwa virtual community adalah agregasi sosial dalam bentuk Internet. Setiap orang membawa permasalahan untuk didiskusikan dalam waktu jangka panjang, melibatkan perasaan atau pikiran dari hubungan yang dibentuk oleh pengguna dengan kedekatan yang tercipta di ruang siber. Virtual community adalah komunitas yang terbentuk melalui komunikasi dengan komputer (Communication Mediated Computer) sebagai perantara. Anggota komunitas dapat saling bergantian dalam berbagi pengalaman dan menikmati konten yang disediakan di media online. Dalam komunitas dunia nyata, pertemuan tatap muka diperlukan untuk menjalin komunikasi, sedangkan dalam komunitas virtual, pertemuan tatap muka tidak diperlukan. Bahkan komunitas seringkali tidak perlu mengenal satu sama lain untuk bergabung dalam sebuah komunitas (Jasmadi, 2008). Virtual communities adalah entitas sosial yang dihasilkan oleh diskusi jangka panjang di antara banyak orang dalam jaringan sosial, dan memiliki perasaan yang cukup tentang hubungan antarpribadi di dunia maya (Budiargo, 2015). Sementara itu, Gary Burnett (2000) menjelaskan bahwa "komunitas virtual berfungsi sebagai forum untuk kedua jenis pencarian informasi," memiliki keuntungan tambahan dibandingkan jenis lingkungan informasi lain.

Raymond Williams (1983) membahas konsepnya tentang mobile privatization, ia berpendapat bahwa pada tingkat sosial yang paling aktif, orang semakin hidup sebagai keluarga kecil yang tertutup, sementara secara bersamaan ada hal-hal privasi yang terbatas. Di mana media memberi kita kesempatan untuk meninggalkan tempat, bahkan tidak harus fisik. Handphone sangat dipribadikan, dirancang untuk pengguna dengan kata sandi yang benar, dengan ikon, karakter, dan gambar yang mengharuskan kita face to screen. Kesimpulan Raymond menjelaskan bahwa manusia tidak lagi membutuhkan ruang publik atau kontak fisik sebagai pendorong interaksi, tetapi komunikasi saat ini lebih terkoordinasi ke layar menggunakan handphone daripada interaksi face to face (Manalu, 2017).

Lebih lanjut, Rheingold menggambarkan orang-orang dalam komunitas virtual menggunakan teks yang mereka ketik di layar untuk bertukar salam dan berdebat, terlibat dalam diskusi intelektual, melakukan transaksi perdagangan, bertukar pengetahuan, berbagi dukungan emosional, membuat rencana, bertukar ide, bergosip, bermusuhan, jatuh cinta, mencari 
teman dan kehilangan mereka, bermain game, dan membuat seni tinggi kecil (Chenault, 1998).

Dengan demikian dapat disimpulkan bahwa komunitas virtual adalah sekumpulan individu maupun kelompok yang menggunakan media internet untuk berinteraksi, berkomunikasi dan berdiskusi satu dengan yang lain, tanpa perlu tatap muka dan bahkan tidak perlu saling mengenal satu sama lain untuk tergabung dalam komunitas tersebut.

Menurut Lisda Rahayu (2014), hakikat layanan perpustakaan adalah penyediaan segala bentuk bahan pustaka secara tepat dan akurat sesuai kebutuhan pemustaka penyediaan berbagai sarana penelusuran informasi. Selain menyediakan bahan pustaka yang dibutuhkan pemustaka, perpustakaan juga harus menyediakan sarana temu balik yang dapat memudahkan pemustaka untuk mencari bahan pustaka yang sesuai dengan kebutuhan informasinya.

Perpustakaan sebagai pusat penelitian (library research) sejalan dengan peran perpustakaan dalam menunjang pelaksanaan salah satu unsur Tridharma Perguruan Tinggi, yaitu penelitian. Dalam peran ini perpustakaan berusaha menjadi pusat referensi bagi para peneliti maupun dosen, mahasiswa dan karyawan dalam mencari sumber-sumber referensi untuk menyelesaikan penelitiannya. Perpustakaan menyiapkan sumber daya manusia yang kompeten dibidangnya dalam rangka memberikan bantuan kepada peneliti. Berbagai jasa bimbingan dilakukan oleh pustakawan di antaranya; pertama, bantuan penelusuran literatur, kedua, melakukan kegiatan berupa layanan bimbingan pemakai (orientasi perpustakaan), ketiga, layanan referensi dasar dan komplek, keempat, layanan bimbingan penyelesaian tugas akhir dan lain-lain.(Nurmayuni, 2020).

Agar tidak tertinggal oleh kemajuan zaman, perpustakaan perlu berinovasi dalam memberikan layanan kepada masyarakat apalagi pada masa pandemi covid-19. Inovasi merupakan aktivitas yang berupa penelitian, pengembangan, atau melakukan rekayasa terhadap suatu produk yang sudah ada sehingga menjadi produk yang memiliki utilitas yang lebih baik dari sebelumnya. Inovasi juga dianggap sebagai pengembangkan penerapan praktis nilai dan konteks ilmu pengetahuan yang baru, atau cara baru untuk menerapkan ilmu pengetahuan dan teknologi (Rizvanda Meyliano Dharma Putra, 2018). 
Kualitas layanan perpustakaan merupakan elemen utama perpustakaan yang harus diperhatikan. Pemustaka yang puas dengan layanan perpustakaan yang disediakan oleh perpuustakaan akan menciptakan citra positif bagi perpustakaan. Sebaliknya, jika pemustaka tidak puas dengan layanan yang disediakan oleh perpustakaan akan mengarah ke citra negatif bagi perpustakaan (AD, 2020). Sebagai unit pendukung di bidang pendidikan, perpustakaan di masa pandemi covid-19 harus tetap memberikan pelayanan yang baik bagi pemustaka yaitu dengan menyediakan sumber informasi elektronik bagi pengguna yang membutuhkannya dengan mengakses melalui internet. Selain itu, layanan perpustakaan yang semula dikembangkan secara tatap muka telah diubah menjadi layanan online untuk memberikan kemudahan bagi pemustaka dan pustakawan pada saat pandemi covid-19. Pustakawan harus kreatif membuat inovasi baru dalam memberikan layanan online kepada pemustaka agar keberdaan perpustakaan sebagai penyedia informasi di masa pandemi covid-19 berjalan dengan baik. Pelayanan perpustakaan yang dapat diberikan kepada pemustaka selama pandemi covid-19 diantaranya ialah:

\section{Layanan Penelusuran Online}

Layanan penelusuran online disediakan untuk memudahkan pemustaka dalam mencari informasi dan bertanya langsung kepada pustakawan yang bertugas di bidang layanan online. Layanan penelusuran online ini biasanya menjadi salah satu menu pada website perpustakaan. Layanan penelusuran online memberikan informasi tentang koleksi-koleksi yang dimiliki perpustakaan. Melalui penelusuran online, pemustaka dapat mencari informasi yang mereka butuhkan kapan saja, dan di mana saja (AD, 2020).

\section{Layanan E-Resources}

Untuk mendukung keberhasilan dan kesuksesan kegiatan pendidikan dan pembelajaran pada semua jenjang pendidikan, baik perpustakaan sekolah maupun perpustakaan universitas harus menyediakan koleksi tercetak dan elektronik (e-resources). Koleksi tercetak meliputi buku, majalah, jurnal, surat kabar, peta, koleksi grey literature, seperti skripsi, tesis, disertasi prosiding konferensi dan bentuk koleksi cetak lainnya. Pada saat yang sama, koleksi elektronik dalam bentuk buku elektronik (e-book), jurnal elektronik (e-journal), baik yang dilanggan maupun yang diterbitkan oleh institusi, dan tersedia secara gratis (open access). Di masa pandemi COVID-19, sumber informasi elektronik sangat membantu dan dibutuhkan untuk mendukung pembelajaran online. Selama pengguna memiliki Internet, mereka dapat mengakses 
sumber informasi elektronik kapan saja dan di mana saja. Setiap orang dapat mengakses sumber informasi elektronik yang dimiliki oleh perpustakaan, akan tetapi ada beberapa sumber informasi yang terbatas pada bagian tertentu untuk di akses. (AD, 2020)

\section{Digital Library}

Upaya yang dilakukan untuk mencegah penyebaran virus Covid-19 di dunia pendidikan, kegiatan belajar dan mengajar maupun perkuliahan dilaksanankansecara online atau daring. Dalam rangka menyediakan sumber informasi untuk pembelajaran dan perkuliahan yang diperlukan memerlukan sumber-sumber informasi yang dapat diakses secara online. Sumber informasi online ini dikenal sebagai sumber informasi digital. Sumber digital ini memberi pengguna akses ke koleksi digital perpustakaan kapan saja, dan di mana saja. Perpustakaan Digital atau Digital Library (Saleh, 2014) adalah organisasi yang menyediakan sumber daya dan staf profesional untuk memilih, mengedit, mengakses, menerjemahkan, mendistribusikan, dan memelihara integritas dan kontinuitas koleksi digital. Sehingga selalu tersedia dan murah untuk digunakan dalam komunitas tertentu atau ditentukan.(AD, 2020)

\section{Literasi Informasi Online}

Literasi informasi bagi pemustaka sangat diperlukan untuk memperlancar dalam pencarian dan pemanfaatan sumber informasi yang dibutuhkan. Literasi informasi yang bisa disajikan perpustakaan kepada pemustaka secara online terdapat beberapa macam. Misalnya pengenalan perpustakaan kepada anggota baru/ siswa baru/ mahasiswa baru, literasi tentang penelusuran sumber informasi, literasi tentang pemanfaatan sumber-sumber informasi, literasi tentang publikasi karya ilmiah, literasi tentang pengecekan plagiasi, dan sebagainya. Literasi secara online bisa dilakukan dengan menggunakan aplikasi Zoom meeting, Google Hangouts Meet, GoToMeeting, FreeConference dan aplikasi lainnya. (AD, 2020)

5. Konsultasi Perpustakaan dan Kepustakawanan Online

Konsultasi kepustakawanan pada masa pandemi bisa dilakukan melalui aplikasi whatsApp, instagram, facebook, sms, telpon, email maupun chatting. Pustakawan dapat memberikan pelayanan konsultasi sepanjang waktu, tidak terbatas pada jam kerja. Kalau konsultasi langsung hanya bisa dilakukan pada saat jam kerja, maka konsultasi online bisa dilakukan kapan saja dan dimana saja. Konsultasi online ini meliputi konsultasi akses informasi elektronik, konsultasi pelayanan 
administrasi, konsultasi penyusunan tugas akhir, konsultasi kepustakawanan seperti penyusunan Dupak dan sebagainya(AD, 2020)

\section{KESIMPULAN}

Berkat peraturan baru bahwa setiap aktivitas harus dilakukan dari rumah, sehingga telah menciptakan kreativitas baru dalam berbagai cara. Berbagai jenis layanan perpustakaan yang sebelumnya hanya dilakukan secara tatap muka atau offline kini dapat dilakukan secara online. Hal ini sangat memudahkan dan meringankan pemustaka dan pustakawan yang harus bekerja dari rumah. Pustakawan dapat berinovasi untuk membantu pemustaka dalam memperoleh informasi elektronik dan layanan administrasi lain yang diperlukan. Melalui berbagai inovasi, pustakawan dapat memperoleh angka kredit untuk kenaikan jabatan dan pangkatnya. Di sisi lain, sangat dibutuhkan dukungan kelembagaan berupa penyediaan sarana dan fasilitas yang diperlukan dalam layanan online berupa sumber informasi elektronik, komputer lengkap, jaringan internet yang bagus, listrik lancar, pelatihan sumber daya manusia diperlukan. Semua faktor tersebut sangat penting dan saling terkait untuk mendukung keberhasilan layanan online di masa pandemi ini.

\section{DAFTAR RUJUKAN}

AD, S. (2020). Layanan Perpustakaan di Masa Pandemi Covid 19. Buletin Perpustakaan Universitas Islam Indonesia, 3(2), 53-64. https://journal.uii.ac.id/Buletin-Perpustakaan/article/view/17798

Chenault, B. G. (1998). Developing Personal and Emotional Relationships Via Computer-Mediated Communication. CMC Magazine. https://www.december.com/cmc/mag/1998/may/chenault.html

Dian Budiargo. (2015). Berkomunikasi Ala Net Generation. PT Elx Media Komputindo.

Fancis Lim. (2008). Filsafat Teknologi Don Ihde Tentang Manusia dan Alat. Kanisius.

Fuchs, C. (2008). Internet and Society: Social Theory in the Information Age. Routledge.

Gary Burnett. (2000). Information exchange in virtual communities: a typology. Information Research, 5(4).

Jasmadi. (2008). Membangun Komunitas Online secara Praktis dan Gratis. Elex Media Computindo. 
Laugu, N. (2021). Kajian Internet dan Masyarakat Virtual. Prodi S2 IIS Konsentrasi Ilmu Perpustakaan Dan Informasi.

Layla Umayya. (2021). Pengertian Internet. http://perpustakaandigitallaylan.weebly.com/ uploads/2/0/5/7/20579744/pengertian_internet.pdf

Manalu, R. M. dan R. (2017). Analisis Pemanfaatan Virtual Community Sebagai Media Komunikasi Kelompok Melalui Sosial Media. Interaksi Online, 5(4), 1-11. https://media.neliti.com/media/publications/185651ID-analisis-pemanfaatan-virtual-community-s.pdf

Moleng, L. J. (2008). Metodelogi Penelitian Kualitatif. Remaja Rosdakarya.

Mukhtar Effendi. (2010). Peranan Internet Sebagai Media Komunikasi. Jurnal Dakwah Dan Komunikasi, 4(1).

http://ejournal.iainpurwokerto.ac.id/index.php/komunika/article/downlo $\mathrm{ad} / 143 / 117$

Nazir, M. (2007). Metode Penelitian. Ghalia Indonesia.

Nurmayuni, S. (2020). Layanan Online Perpustakaan Perguruan Tinggi Sebelum Dan Sesudah Pandemi Covid-19: Studi Perpustakaan UIN Sunan Ampel Sejak 2018 Hingga 2020. 4(1), 23-40.

Putri Maulina. (2018). Warung Kopi, Masyarakat Virtual, Dan Hiperealitas (Ketika Warung Kopi Mengaburkan Batasan Realita). Jurnal Ilmu Komunikasi, 4(1). https://doi.org/DOI: https://doi.org/10.35308/source.v4i1.736

Rahayu, L. (2014). Dasar-dasar Layanan Perpustakaan. Universitas Terbuka.

Rizvanda Meyliano Dharma Putra. (2018). Inovasi Pelayanan Publik Di Era Disrupsi (Studi Tentang Keberlanjutan Inovasi E-Health Di Kota Surabaya). Universitas Airlangga.

Rulli Nasrullah. (2015). Media Sosial. Simbiosa Rekatama Media.

Shinta Nofita Sari. (2018). Perilaku Demokratik Masyarakat Virtual (Studi Kasus: Pemustaka Perpustakaan Uin Sunan Kalijaga Yogyakarta). Jurnal Pustaka Ilmiah, 4(1).

https://doi.org/https://doi.org/10.20961/jpi.v4i1.33808. 